\title{
Genetic diversity and environmental stress in Italian populations of the cyprinodont fish Aphanius fasciatus
}

\section{Diversité génétique et stress de l'environnement chez des populations du poisson cyprinidé Aphanius fasciatus}

\author{
Roberta Cimmaruta, Fabrizio Scialanca, Fabio Luccioli, Giuseppe Nascetti *
}

Department of Environmental Sciences, Tuscia University, Piazza dell'Università, 01100 Viterbo, Italy

Received 31 July 2002; accepted 30 September 2002

\begin{abstract}
Allozyme electrophoresis has been used to analyse the genetic structure of ten populations of the killifish, Aphanius fasciatus, sampled from Italian coastal brackish lagoons or salterns. The goal of the study was to compare the genetic structure of samples obtained from habitats characterised by environmental stress of different kinds, with the aim of gaining a better understanding of the relationships between the genetic variation of natural populations and environmental disturbance, either natural or man-made. Therefore, the sampling scheme has been planned to provide samples from both brackish habitats, characterised by natural stress with seasonal marked fluctuations of chemical and physical parameters, and from coastal lagoons suffering from a high human impact due to fishing, pollution, aquaculture, etc. Many sample pairs from the two sets were also geographically very close, allowing a better comparison of the genetic variation of populations tolerating different kinds of environmental stress (i.e., natural vs. anthropogenic). The obtained data evidence three main genetically distinct population groups, including samples from: (1) central-northern Tyrrhenian and northern Sardinian coasts; (2) southern Tyrrhenian and southern Sardinian coasts; (3) Adriatic Sea. Within the two Tyrrhenian groups, a general trend indicates a lower genetic variability for the samples obtained from highly human disturbed brackish waters. In particular, samples characterised by well documented pollution and dystrophic crises (i.e., Orbetello and Cagliari-Santa Gilla lagoons) have a lower genetic variability with respect to nearby scarcely disturbed populations (Tarquinia saltern and Sant'Antioco lagoon). The Adriatic populations exhibit a low level of genetic variation, which may be due to the persistent hypoxic condition of the sea basin combined with the paleogeographic history of the area.
\end{abstract}

(C) 2003 Éditions scientifiques et médicales Elsevier SAS and Ifremer/CNRS/IRD. All rights reserved.

Résumé

Dix populations d'Aphanius fasciatus provenant de lagunes côtières et d'étangs saumâtres italiens ont été génétiquement caractérisées grâce à l'électrophorèse multilocus. L'étude confronte la structure génétique de populations venant d'habitats caractérisés par différents types de stress du milieu pour améliorer la connaissance des relations entre le degré de variabilité génétique des populations naturelles et la perturbation du milieu, qu'elle soit naturelle ou anthropogénique. Aussi, l'échantillonnage a-t-il été planifié pour obtenir des populations naturellement perturbées (avec de grandes variations des paramètres physiques et chimiques) ou bien subissant une perturbation due à la pêche, à la pollution, à l'aquaculture. Plusieurs couples d'échantillons de ces deux types ont été prélevés sur des sites géographiquement proches pour faciliter la comparaison entre les populations qui supportent les deux types de stress. Trois groupes génétiquement différents ont été identifiés : le premier est constitué par les populations de la haute et moyenne Tyrrhénienne et des côtes septentrionales de la Sardaigne, le second par celles de la basse Tyrrhénienne et de la Sardaigne méridionale et le troisième par celles de la côte Adriatique. Pour les deux groupes de populations de la Tyrrhénienne, une tendance à une moindre variabilité génétique concernant les populations soumises à un habitat troublé par l'activité humaine apparaît. C'est particulièrement le cas pour les échantillons de lagunes côtières polluées ou qui ont été victimes de crises dystrophiques (par exemple Orbetello et Cagliari-Santa Gilla); la variabilité génétique est inférieure comparée aux populations géographiquement proches mais qui vivent dans un habitat pratiquement inaltéré (saline de Tarquinia et lagune de Sant'Antioco). En général, les populations

\footnotetext{
* Corresponding author.

E-mail address: nascetti@unitus.it (G. Nascetti).
} 
de la zone Adriatique montrent une faible variabilité génétique, peut-être à cause du déficit persistant d'oxygène du bassin ou à cause de la récente histoire paléographique de cet emplacement.

(c) 2003 Éditions scientifiques et médicales Elsevier SAS and Ifremer/CNRS/IRD. Tous droits réservés.

Keywords: Aphanius fasciatus; Heterozygosity; Allozymes; Brackish waters; Environmental stress

Mots clés : Aphanius fasciatus ; Hétérozygotie ; Allozymes ; Eaux saumâtres ; Stress du milieu

\section{Introduction}

To understand the mechanisms underlying evolutionary processes, with particular regard to biodiversity generation and maintenance, it is essential to look at interactions between the organisms and the environment. Recent studies demonstrate a strong link between environmental stress and biodiversity levels at various scales: genes, individuals, populations, and communities (Nevo, 2001).

The relationships between genetic diversity and environmental stress have been evidenced in natural populations for a long time (Heuts, 1948; Levine, 1952; Crow, 1957). More recently, the biochemical and molecular approaches have deeply investigated the correlation between the genetic structure of natural populations and the levels of environmental stress (Hartl et al., 1985; Watt, 1985; Hoffmann and Parsons, 1991). Fishes and other marine organisms have shown, in many cases, a close correlation between genetic polymorphism and ecological response to habitat challenge (Nevo et al., 1984; Diehl et al., 1986; Cognetti, 1994, 1999; Cognetti and Maltagliati, 2000; Nevo, 2001; Dufresne et al., 2002). The big number of cases studying the relationships between environmental disturbance and population genetic diversity has allowed a good comprehension and has aided in the formulation of a theoretical approach to the biological mechanisms involved in this process (Barton and Turelli, 1990).

The environmental stress acts on natural populations in different ways: (1) randomly, strongly reducing the size of the populations and causing, as a consequence, the loss of a random number of alleles, resulting in a reduction of genetic variability and heterozygosity (a phenomenon known as genetic erosion); (2) selectively, causing different mortality rates for the various genotypes, lowering the abundance of the less resistant ones and, therefore, changing the genotypic frequencies in the populations involved; (3) establishing alternative reproductive strategies such as parthenogenesis, hermaphroditism, scissiparity, etc.

Brackish waters are spontaneously subject to wide daily and seasonal variations of ecological parameters and are therefore habitats characterised by a high degree of environmental stress. Moreover, when used by man as salt-works, for extensive aquaculture or other activities, the human impact becomes another source of environmental stress. Coastal lagoons, estuaries and other brackish waters, therefore, provide a good opportunity to investigate the relation- ships between biodiversity and environmental stress, either natural or caused by man.

The killifish, Aphanius fasciatus Nardo 1827, is a cyprinodont fish inhabiting brackish waters and is a good target species for ecological and evolutionary studies. It is indeed quite common in coastal brackish habitats of the central Mediterranean area (Tortonese, 1986) and is able to tolerate a wide range of variations of relevant chemical-physical parameters such as temperature and salinity.

In the present study, the genetic structure of 10 Italian populations of $A$. fasciatus was assessed using allozyme electrophoresis. The aim was to compare the degree of genetic variability and the environmental quality at each sampling site to provide a better understanding of the relationships occurring between the genetic variation of natural populations and the kind of environmental disturbance, either natural or human-induced. Therefore, the sampling scheme has been planned to provide two sets of samples. The first one was obtained from brackish habitats characterised by natural stress, with seasonal marked fluctuations of chemical and physical parameters (mainly temperature and salinity). The second set was collected in coastal lagoons suffering from human impact due to fishing, pollution, aquaculture, etc. Many sample pairs from the two sets were also geographically very close (e.g. Tarquinia/Orbetello from the central Tyrrhenian coast) allowing a better comparison of the genetic variability of populations tolerating different kinds of environmental stress (i.e., natural vs. anthropogenic).

\section{Materials and methods}

\subsection{Collection of samples}

An overall number of 779 individuals of A. fasciatus were collected by fish-traps from each of the following 10 coastal localities Fig. 1): ORB, Orbetello lagoon; TAR, Tarquinia salterns; ORI, Oristano coastal lake; SAN, Sant'Antioco lagoon; CAG, Cagliari-Santa Gilla lagoon; MAR, Marsala salterns; MSV, Margherita di Savoia salterns; LES, Lesina coastal lake; CER, Cervia salterns; GOR, Goro lagoon. Sampling was carried out in years 1999-2000, except at sites from Orbetello lagoon and Tarquinia salterns, that were sampled in 1996. The number of specimens studied per locality is given in Fig. 1. Whole specimens were stored in separate plastic bags at $-80^{\circ} \mathrm{C}$ and dissected just before the electrophoretic analysis. 


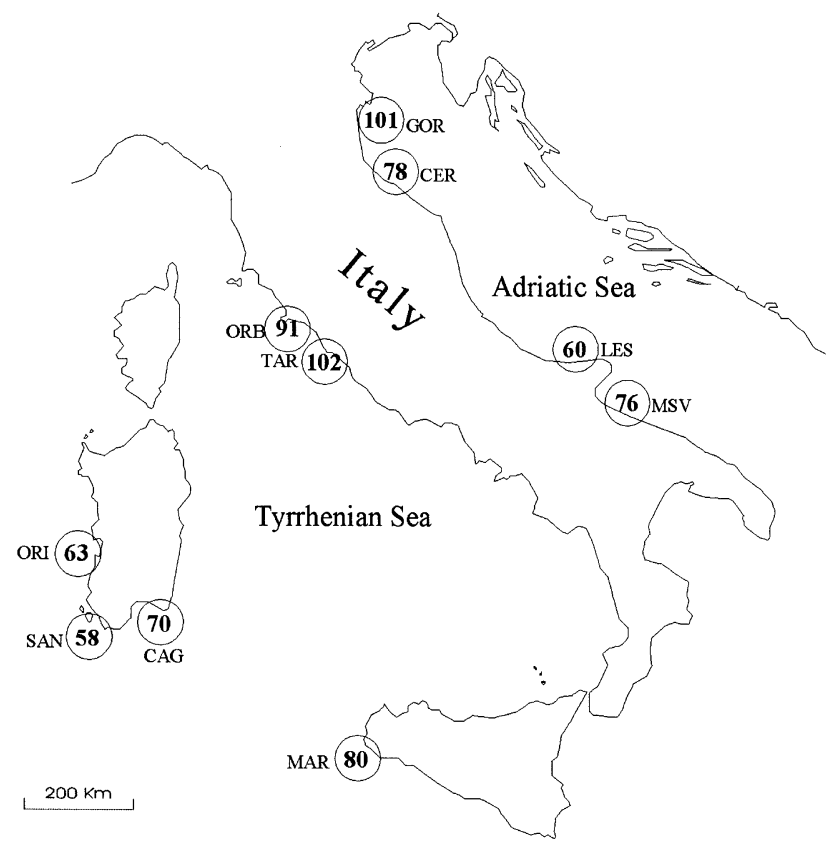

Fig. 1. Sampling sites and number of Aphanius fasciatus specimens collected.

\subsection{Electrophoretic methods and data analysis}

The genetic study was carried out on muscle, liver and eye extracts. Electrophoretic analyses were performed on starch gel (12\%), using modified methods from Selander et al. (1979) and Pasteur et al. (1987). Enzyme loci are referred to using the Shaklee et al. (1990) nomenclature. At each studied locus, the reference allele, named 100, designates by convention the most frequent electromorph in the sample from Tarquinia salterns. Table 1 shows the enzymes studied and the buffers used. Electrophoretic data were analysed using the computer package Biosys-1 (Swofford and Selander, 1989). Genotypic distributions at all loci were tested for conformance to Hardy-Weinberg equilibrium using the exact probability test. Genetic variability was estimated using the following parameters: (1) overall number of alleles per locus $\left(A_{\mathrm{Tot}}\right)$; (2) percentage of polymorphic loci, using the 99\% $\left(P_{99}\right)$ criterion; $(3)$ observed $\left(H_{\mathrm{o}}\right)$ and expected $\left(H_{\mathrm{e}}\right)$ mean heterozygosity. The statistical significance of differences in the level of the genetic variability between studied populations was tested applying a paired $t$-test to arcsine square-root transformed values of observed heterozygosity per locus (Archie, 1985) at all the 45 population pairs. $H_{\mathrm{o}}$ has been used because some deviations from Hardy-Weinberg equilibrium have been found, preventing $H_{\mathrm{e}}$ employment. The obtained $P$ results have been adjusted using Bonferroni correction $(\alpha=0.05)$. Genetic structuring within and be-

Table 1

Enzyme systems assayed in Aphanius fasciatus samples

\begin{tabular}{|c|c|c|c|c|c|c|}
\hline Enzyme & Abbreviation & E.C. no. & $\begin{array}{l}\text { Number of loci } \\
\text { observed }\end{array}$ & Buffer system ${ }^{a}$ & Tissue $^{\mathrm{b}}$ & Reference $^{c}$ \\
\hline Glycerol-3-P dehydrogenase & GPDH & 1.1 .1 .8 & 2 & 6 or 3 & $\mathrm{M}, \mathrm{L}$ & $\mathrm{d}$ \\
\hline L-Lactate dehydrogenase & LDH & 1.1.1.28 & 3 & 4 or 1 & $\mathrm{E}, \mathrm{M}$ & $\mathrm{a}$ \\
\hline Malate dehydrogenase & $\mathrm{MDH}$ & 1.1.1.37 & 3 & 6 & M & $\mathrm{b}$ \\
\hline Malic enzyme & ME & 1.1.1.40 & 2 & 2 & M & $\mathrm{d}$ \\
\hline Isocitrate dehydrogenase & IDH & 1.1.1.42 & 2 & 2 & M, L & $\mathrm{b}$ \\
\hline 6-Phosphogluconate dehydr. & 6PGDH & 1.1.1.43 & 1 & 6 & M & $\mathrm{b}$ \\
\hline Glucose-6-P dehydrogenase & G6PDH & 1.1.1.49 & 1 & 6 & M & $\mathrm{b}$ \\
\hline Glyceraldehyde-3-P dehydrog. & GAPDH & 1.2.1.12 & 1 & 2 & M & $b, d$ \\
\hline Glutamate dehydrogenase & GDH & 1.4.1.3 & 1 & 2 & $\mathrm{~L}$ & d \\
\hline Superoxide dismutase & SOD & 1.15.1.1 & 1 & 2 or 1 & M & $\mathrm{c}$ \\
\hline Aspartate aminotransferase & AAT & 2.6.1.1 & 2 & 6 & M, L & $\mathrm{c}$ \\
\hline Creatine kinase & CK & 2.7.3.2 & 1 & 2 & M & $\mathrm{b}$ \\
\hline Adenilate kinase & $\mathrm{ADK}$ & 2.7.4.3 & 1 & 2 & M & d \\
\hline Esterase & EST & 3.1.1.2 & 2 & 3 or 1 & M & $\mathrm{d}$ \\
\hline Peptidase (Leu-Gly-Gly) & PEP-B & 3.4 .11 & 1 & 2 & M & f \\
\hline Adenosine deaminase & ADA & 3.5.4.4 & 1 & 2 & M & $\mathrm{e}$ \\
\hline Carbonic anhydrase & $\mathrm{CA}$ & 4.2.1.1 & 1 & 3 or 2 & M & $\mathrm{e}$ \\
\hline Aconitase & $\mathrm{ACO}$ & 4.2 .1 .3 & 1 & 5 & M & $\mathrm{e}$ \\
\hline Mannose-6-P isomerase & MPI & 5.3.1.8 & 1 & 2 or 3 & M & $\mathrm{e}$ \\
\hline Glucose-6-P isomerase & GPI & 5.3.1.9 & 3 & 6 & $\mathrm{M}, \mathrm{E}$ & $\mathrm{c}$ \\
\hline Phosphoglucomutase & PGM & 5.4.2.2 & 2 & 4 & M & $\mathrm{a}$ \\
\hline
\end{tabular}

${ }^{a}$ Buffer systems are the following: (1) discontinuous tris/citrate (Poulik, 1957); (2) continuous tris/citrate (Selander et al., 1971); (3) tris/versene/borate (Brewer and Sing, 1970); (4) tris/versene/maleate (Brewer and Sing, 1970); (5) lithium/borate (Soltis et al., 1983); (6) phosphate/citrate (Harris and Hopkinson, 1976).

${ }^{\mathrm{b}} \mathrm{M}=$ muscle; $\mathrm{L}=$ liver; $\mathrm{E}=$ eye

c Staining references: (a) Brewer and Sing (1970); (b) Shaw and Prasad (1970); (c) Selander et al. (1971); (d) Ayala et al. (1972); (e) Harris and Hopkinson (1976); (f) Richardson et al. (1986). 
tween populations was calculated using the $F$ statistics by Wright $(1943,1951)$. Nei's distances (Nei, 1978, $\left.D_{\mathrm{Nei}}\right)$ were used to estimate genetic divergence between populations and to build an UPGMA dendrogram (Sneath and Sokal, 1973) to show the genetic relationships between the studied populations.

The amount of gene flow between populations was estimated by means of the parameter $\mathrm{Nm}$, where $m$ is the fraction of immigrants in a population of effective size $N$, using the formula proposed by Wright $(1943,1951)$, modified by Crow and Aoki (1984): $N m=\left[\left(1 / F_{\mathrm{ST}}\right)-1\right] / 4 \alpha$ where $F_{\mathrm{ST}}$ is the standardised variance of allele frequencies (averaged over variable loci) and $\alpha=(n / n-1)^{2}$, with $n$ being the number of populations sampled.

The computer software Bottleneck (Piry et al., 1999) was used to infer recent bottlenecks in sampled populations using two-tailed Wilcoxon sign-rank test (Luikart et al., 1998) under infinite allele mutation (IAM) model (Kimura and Crow, 1964).

\section{Results}

The 10 samples of A. fasciatus were investigated for 33 putative gene loci. Six of these loci were found to be monomorphic in all the studied samples (LDH-3, MDH-2, IDH-1, SOD, CK and ADK). The remaining 27 loci were polymorphic and their allele frequencies are shown in Table 2 Twelve loci are moderately polymorphic, with the most common allele fixed in most of the populations sampled and reaching frequencies above $85 \%$ in the few polymorphic samples (GPDH-1, GPDH-2, GAPDH, LDH-2, MDH-4, ME-1, 6PGDH, AAT-1, EST-1, EST-3, CA, GDH). The remaining 15 loci show from two to five alleles per population at variable percentages. The 10 studied samples share the same common allele (100) at 19 of the polymorphic loci, while at eight loci (LDH-1, MDH-1, ME-2, AAT-3, GPI-3, PGM-1, PGM-2, ACO), there are two or three alleles showing in turn the higher percentages in the various populations sampled. Twenty-two private alleles, i.e., alleles found in a single population (Neel, 1973), have been observed at 17 loci. The frequencies of these private alleles are quite low: 14 out of 22 have frequencies up to $2.5 \%$, while the other eight range from $4 \%$ to $13 \%$.

All the populations were in Hardy-Weinberg equilibrium except Orbetello (ORB), Marsala (MAR) and Goro (GOR). These three samples showed a significant deficit of heterozygotes at one locus each (PGM-1, G6PDH and MDH-1, respectively), even after pooling the rare alleles (Table 3). To test for recent bottlenecks, the three loci not in Hardy-Weinberg equilibrium were omitted (PGM-1, G6PDH and MDH-1) and then the Wilcoxon sign-rank test under IAM model was carried out. None of the 10 studied populations showed signs of recent bottlenecks, as reported in Table 3

Genetic variability parameters have been estimated highlighting a wide range of values Table 3 . The total number of alleles per population $A_{\text {Tot }}$ ranged from 38 (CER) to 59
(TAR), the percentage of polymorphic loci $P_{99}$ varied from $15.2 \%$ (CER) to $63.6 \%$ (TAR), and the values of the mean observed heterozygosity $H_{\mathrm{o}}$ ranged between 0.045 (GOR) and 0.147 (TAR). The sample from Tarquinia exhibits the highest values of genetic variability with the other Tyrrhenian samples also having high levels of genetic variability, except Orbetello population (ORB). This sample has the lowest values, together with the Adriatic ones (GOR, CER, LES, MSV). The $t$-test on single locus observed heterozygosity has shown 19 significant comparisons out of the 45 tests carried out. After applying Bonferroni correction, four comparisons were still significant (TAR vs. ORB, LES, CER, GOR).

The analysis of the estimated genetic distances showed a substantial genetic similarity of the studied populations Table 4, with a range of Nei's (1978) $D$ between 0.003 (CER-GOR) and 0.130 (TAR-CAG). The two samples from the central Tyrrhenian coast (TAR, ORB) are genetically most differentiated, showing Nei's $D$ between 0.04 and 0.130 from the other samples. The other eight populations instead exhibit lower genetic distances between each other, ranging from 0.003 to 0.046 , in spite of being geographically quite apart and coming from different sea basins (Tyrrhenian and Adriatic). The parameters of genetic diversity show a mean $F_{\text {ST }}$ value of $0.306\left(F_{\text {IT }}=0.319 ; F_{\text {IS }}=0.019\right)$ due mainly to the two loci LDH-1 and ME-2, having the highest $F_{\mathrm{ST}}$ values (0.549 and 0.748 , respectively). This is because these loci show the two alleles LDH- ${ }^{100}$ and ME- $2^{100}$ at very high frequencies in the Tyrrhenian samples ORB and TAR, while lacking $\left(\mathrm{LDH}-1^{100}\right)$ or at low frequencies $\left(\mathrm{ME}-2^{100}\right)$ in all the other populations. The stronger differentiation of the populations ORB and TAR is evidenced in the UPGMA dendrogram obtained from Nei's distances Fig. 2 and identifying two main clusters. The first group consists of Orbetello and Tarquinia that are clearly differentiated from the other samples, all included in a second cluster. This second cluster observed in the dendrogram is divided into two main subclusters comprising Adriatic (MSV, LES, CER, GOR) and Sardinian-Sicilian (SAN, ORI, CAG, MAR) populations, respectively. Within the Adriatic sub-cluster, the four populations are arranged following a geographical pattern, with geographically nearer populations also showing the closer genetic relationships. On the contrary, in the southern Tyrrhenian group, the genetic relationships are independent of the geographic distances between samples.

\section{Discussion}

The genetic structure of Italian populations of the killifish A. fasciatus has shown the existence of two main groups of genetically similar populations. The first one includes the samples from central Tyrrhenian Sea (ORB and TAR), while the populations from southern Tyrrhenian and Adriatic seas are included in the second group as two separated subclusters. This geographic subdivision of killifish populations is in agreement with the results of previous electrophoretic 
Table 2

Allele frequencies at the 27 polymorphic loci in the studied populations of A. fasciatus.

The asterisks indicate loci not in Hardy-Weinberg equilibrium in the corresponding populations

\begin{tabular}{|c|c|c|c|c|c|c|c|c|c|c|}
\hline Locus/allele & ORB & TAR & ORI & SAN & CAG & MAR & MSV & LES & CER & GOR \\
\hline \multicolumn{11}{|l|}{$\overline{G P D H-1}$} \\
\hline 92 & - & 0.061 & - & - & - & - & - & - & - & - \\
\hline 100 & 1.000 & 0.939 & 1.000 & 1.000 & 1.000 & 0.990 & 0.889 & 1.000 & 1.000 & 1.000 \\
\hline 106 & - & - & - & - & - & 0.010 & 0.111 & - & - & - \\
\hline \multicolumn{11}{|l|}{$G P D H-2$} \\
\hline 92 & 0.024 & 0.143 & - & - & 0.036 & - & - & - & - & - \\
\hline 100 & 0.976 & 0.857 & 1.000 & 1.000 & 0.964 & 1.000 & 1.000 & 1.000 & 1.000 & 1.000 \\
\hline \multicolumn{11}{|l|}{$L D H-1$} \\
\hline 100 & 0.667 & 0.597 & - & - & - & - & - & - & - & - \\
\hline 110 & 0.333 & 0.403 & 0.935 & 1.000 & 1.000 & 1.000 & 1.000 & 1.000 & 1.000 & 1.000 \\
\hline 117 & - & - & 0.065 & - & - & - & - & - & - & - \\
\hline \multicolumn{11}{|l|}{$L D H-2$} \\
\hline 100 & 1.000 & 1.000 & 0.929 & 0.977 & 0.989 & 1.0001 .000 & 1.000 & 1.000 & 1.000 & \\
\hline 115 & - & - & 0.071 & 0.023 & 0.011 & - & - & - & - & - \\
\hline$M D H-1$ & & & & & & & & & & $* * *$ \\
\hline 100 & 0.989 & 0.958 & 1.000 & 0.918 & 1.000 & 0.988 & 0.993 & 1.000 & 0.459 & 0.549 \\
\hline 104 & 0.011 & 0.042 & - & 0.082 & - & 0.013 & 0.007 & - & 0.541 & 0.451 \\
\hline \multicolumn{11}{|l|}{$M D H-4$} \\
\hline 100 & 1.000 & 0.994 & 1.000 & 1.000 & 1.000 & 1.000 & 1.000 & 1.000 & 1.000 & 1.000 \\
\hline 104 & - & 0.006 & - & - & - & - & - & - & - & - \\
\hline \multicolumn{11}{|l|}{$M E-1$} \\
\hline 98 & 0.019 & - & - & - & - & - & - & - & - & - \\
\hline 100 & 0.981 & 1.000 & 1.000 & 1.000 & 1.000 & 1.000 & 1.000 & 1.000 & 1.000 & 1.000 \\
\hline \multicolumn{11}{|l|}{$M E-2$} \\
\hline 92 & - & 0.006 & - & - & - & - & - & - & - & - \\
\hline 100 & 0.991 & 0.994 & 0.269 & 0.173 & - & 0.094 & - & - & - & 0.006 \\
\hline 105 & - & - & - & - & - & - & - & 0.033 & - & 0.006 \\
\hline 112 & 0.009 & - & 0.731 & 0.827 & 1.000 & 0.906 & 1.000 & 0.967 & 1.000 & 0.987 \\
\hline \multicolumn{11}{|l|}{$I D H-2$} \\
\hline 93 & - & - & 0.071 & 0.250 & 0.154 & - & - & - & - & - \\
\hline 97 & - & 0.071 & - & - & - & - & - & - & - & - \\
\hline 100 & 1.000 & 0.929 & 0.929 & 0.750 & 0.846 & 1.000 & 0.923 & 1.000 & 1.000 & 1.000 \\
\hline 112 & - & - & - & - & - & - & 0.077 & - & - & - \\
\hline \multicolumn{11}{|l|}{$6 P G D H$} \\
\hline 100 & 1.000 & 0.984 & 1.000 & 1.000 & 1.000 & 1.000 & 1.000 & 1.000 & 1.000 & 1.000 \\
\hline 110 & - & 0.016 & - & - & - & - & - & - & - & - \\
\hline G6PDH & & & & & & $* * *$ & & & & \\
\hline 100 & 0.992 & 0.914 & 1.000 & 1.000 & 1.000 & 0.760 & 1.000 & 1.000 & 1.000 & 1.000 \\
\hline 110 & 0.008 & 0.086 & - & - & - & 0.240 & - & - & - & - \\
\hline \multicolumn{11}{|l|}{ GAPDH } \\
\hline 100 & 0.992 & 1.000 & 1.000 & 1.000 & 1.000 & 1.000 & 1.000 & 1.000 & 1.000 & 1.000 \\
\hline 110 & 0.008 & - & - & - & - & - & - & - & - & - \\
\hline \multicolumn{11}{|l|}{$G D H$} \\
\hline 90 & - & - & - & 0.042 & - & - & - & - & - & - \\
\hline 100 & 1.000 & 1.000 & 1.000 & 0.958 & 1.000 & 1.000 & 0.975 & 1.000 & 1.000 & 1.000 \\
\hline 104 & - & - & - & - & - & - & 0.025 & - & - & - \\
\hline \multicolumn{11}{|l|}{$A A T-1$} \\
\hline 90 & - & - & - & - & - & 0.018 & - & - & 0.022 & - \\
\hline 100 & 1.000 & 1.000 & 1.000 & 1.000 & 1.000 & 0.982 & 1.000 & 0.980 & 0.978 & 1.000 \\
\hline 110 & - & - & - & - & - & - & - & 0.020 & - & - \\
\hline \multicolumn{11}{|l|}{$A A T-3$} \\
\hline 100 & 0.714 & 0.833 & 0.769 & 0.536 & 0.464 & 0.500 & 0.750 & 1.000 & 0.214 & 0.462 \\
\hline 112 & 0.286 & 0.167 & 0.231 & 0.464 & 0.536 & 0.500 & 0.250 & - & 0.786 & 0.538 \\
\hline
\end{tabular}


Table 2

(continued)

\begin{tabular}{|c|c|c|c|c|c|c|c|c|c|c|}
\hline Locus/allele & ORB & TAR & ORI & SAN & CAG & MAR & MSV & LES & CER & GOR \\
\hline \multicolumn{11}{|l|}{ EST-1 } \\
\hline 100 & 1.000 & 1.000 & 1.000 & 1.000 & 1.000 & 0.990 & 1.000 & 1.000 & 1.000 & 1.000 \\
\hline 105 & - & - & - & - & - & 0.010 & - & - & - & - \\
\hline \multicolumn{11}{|l|}{ EST-3 } \\
\hline 100 & 1.000 & 0.866 & 1.000 & 1.000 & 1.000 & 1.000 & 1.000 & 1.000 & 1.000 & 1.000 \\
\hline 105 & - & 0.134 & - & - & - & - & - & - & - & - \\
\hline \multicolumn{11}{|l|}{$P E P-B$} \\
\hline 96 & 0.042 & 0.179 & 0.136 & 0.212 & 0.100 & - & - & - & - & - \\
\hline 100 & 0.958 & 0.821 & 0.864 & 0.788 & 0.900 & 1.000 & 1.000 & 1.000 & 1.000 & 1.000 \\
\hline \multicolumn{11}{|l|}{$A D A$} \\
\hline 94 & - & 0.011 & - & - & - & 0.038 & - & - & - & - \\
\hline 100 & 0.880 & 0.596 & 1.000 & 0.969 & 1.000 & 0.962 & 0.949 & 1.000 & 1.000 & 0.989 \\
\hline 108 & 0.120 & 0.394 & - & 0.031 & - & - & 0.051 & - & - & 0.011 \\
\hline \multicolumn{11}{|l|}{$C A$} \\
\hline 100 & 0.992 & 0.980 & 1.000 & 1.000 & 1.000 & 0.987 & 0.993 & 1.000 & 1.000 & 1.000 \\
\hline 108 & 0.008 & 0.020 & - & - & - & 0.013 & 0.007 & - & - & - \\
\hline \multicolumn{11}{|l|}{$A C O$} \\
\hline 97 & - & 0.077 & - & 0.089 & 0.042 & - & - & - & - & - \\
\hline 100 & 1.000 & 0.885 & 0.788 & 0.344 & 0.390 & 0.670 & 1.000 & 0.970 & 1.000 & 1.000 \\
\hline 110 & - & 0.038 & 0.212 & 0.567 & 0.568 & 0.330 & - & 0.030 & - & - \\
\hline \multicolumn{11}{|l|}{$M P I$} \\
\hline 95 & - & - & - & 0.145 & 0.265 & 0.063 & 0.197 & 0.017 & - & - \\
\hline 100 & 0.672 & 0.652 & 1.000 & 0.791 & 0.735 & 0.880 & 0.803 & 0.983 & 1.000 & 1.000 \\
\hline 104 & 0.328 & 0.342 & - & 0.064 & - & 0.057 & - & - & - & - \\
\hline 107 & - & 0.005 & - & - & - & - & - & - & - & - \\
\hline \multicolumn{11}{|l|}{ GPI-1 } \\
\hline 85 & 0.144 & 0.366 & - & 0.009 & - & - & - & - & - & - \\
\hline 90 & - & - & - & - & 0.026 & 0.062 & - & 0.144 & - & - \\
\hline 93 & - & - & - & - & 0.026 & - & - & - & - & - \\
\hline 100 & 0.856 & 0.634 & 0.976 & 0.918 & 0.935 & 0.900 & 1.000 & 0.763 & 1.000 & 1.000 \\
\hline 104 & - & - & 0.012 & 0.009 & - & - & - & - & - & - \\
\hline 108 & - & - & - & - & 0.006 & - & - & - & - & - \\
\hline 115 & - & - & 0.012 & 0.064 & 0.006 & 0.038 & - & 0.093 & - & - \\
\hline \multicolumn{11}{|l|}{ GPI-3 } \\
\hline 90 & - & - & - & 0.019 & - & - & - & - & - & - \\
\hline 94 & - & - & 0.262 & 0.296 & 0.739 & 0.367 & - & - & - & - \\
\hline 97 & - & - & - & - & - & 0.006 & - & - & - & - \\
\hline 100 & 0.933 & 0.930 & 0.738 & 0.685 & 0.261 & 0.627 & 0.947 & 0.992 & 1.000 & 0.995 \\
\hline 104 & 0.067 & - & - & - & - & - & - & - & - & - \\
\hline 108 & - & 0.070 & - & - & - & - & 0.053 & 0.008 & - & 0.005 \\
\hline \multicolumn{11}{|l|}{ GPI-4 } \\
\hline 85 & 0.155 & 0.379 & - & - & - & - & - & - & - & - \\
\hline 90 & - & - & - & 0.025 & - & 0.054 & - & 0.250 & - & - \\
\hline 100 & 0.845 & 0.621 & 0.957 & 0.900 & 0.975 & 0.929 & 1.000 & 0.750 & 1.000 & 1.000 \\
\hline 104 & - & - & 0.043 & 0.075 & 0.025 & 0.018 & - & - & - & - \\
\hline$P G M-1$ & $* * *$ & & & & & & & & & \\
\hline 90 & - & 0.167 & - & - & - & - & - & - & - & - \\
\hline 94 & 0.213 & 0.237 & 0.271 & 0.437 & 0.829 & 0.424 & 0.633 & 0.625 & 0.894 & 0.920 \\
\hline 100 & 0.770 & 0.564 & 0.729 & 0.552 & 0.164 & 0.127 & 0.283 & 0.375 & - & 0.074 \\
\hline 102 & - & - & - & - & - & - & 0.083 & - & 0.106 & - \\
\hline 104 & 0.016 & 0.032 & - & 0.010 & 0.007 & 0.449 & - & - & - & 0.006 \\
\hline \multicolumn{11}{|l|}{$P G M-2$} \\
\hline 90 & - & - & - & - & - & 0.013 & - & - & - & - \\
\hline 95 & - & 0.016 & 0.488 & 0.640 & 0.681 & 0.584 & 0.454 & 0.857 & 0.714 & 0.702 \\
\hline 100 & 1.000 & 0.984 & 0.512 & 0.360 & 0.312 & 0.390 & 0.546 & 0.143 & 0.286 & 0.298 \\
\hline 105 & - & - & - & - & 0.007 & 0.013 & - & - & - & - \\
\hline
\end{tabular}


Table 3

The killifish populations sampled, listed with the kind of environment and stress tolerated, the genetic variability parameters $\left(H_{\mathrm{o}}, P_{99}\right.$ and $\left.A_{\text {Tot }}\right)$, the conformance to Hardy-Weinberg equilibrium (with the Fixation Index $F$ at loci not in equilibrium) and the probability values of the Wilcoxon sign-rank test for recent bottlenecks under IAM model

\begin{tabular}{llllllll}
\hline Population & Environment & Stress & $H_{\mathrm{o}}$ & $P_{99}$ & $A_{\text {Tot }}$ & Hardy-Weinberg equilibrium & $\begin{array}{l}\text { Wilcoxon test } \\
P \text { values }\end{array}$ \\
\hline ORB & Lagoon & Anthropic & $0.079(0.025)$ & 48.5 & 50 & No, PGM-1, $F=0.455, P<0.001$ & 0.599 \\
TAR & Saltern & Natural & $0.147(0.033)$ & 63.6 & 59 & Yes & 0.865 \\
ORI & Coastal lake & Anthropic & $0.098(0.029)$ & 36.4 & 46 & Yes & 0.424 \\
SAN & Lagoon & Natural & $0.130(0.031)$ & 45.5 & 54 & Yes & 0.389 \\
CAG & Lagoon & Anthropic & $0.096(0.029)$ & 36.4 & 51 & Yes & 0.677 \\
MAR & Saltern & Natural & $0.107(0.032)$ & 48.5 & 56 & No, G6PDH, $F=0.421, P<0.005$ \\
MSV & Saltern & Natural & $0.074(0.026)$ & 33.3 & 45 & Yes & 0.679 \\
LES & Coastal lake & Anthropic & $0.052(0.022)$ & 27.3 & 43 & Yes & 0.966 \\
CER & Saltern & Natural & $0.046(0.022)$ & 15.2 & 38 & Yes & 0.065 \\
GOR & Lagoon & Anthropic & $0.045(0.022)$ & 21.2 & 42 & No, MDH- $1, F=0.227, P<0.05$ & 0.989 \\
\hline
\end{tabular}

Table 4

Matrix of Nei's (1978) genetic distance coefficients. Population abbreviations are as in Fig. 1

\begin{tabular}{|c|c|c|c|c|c|c|c|c|c|c|}
\hline Population & ORB & TAR & ORI & SAN & $\mathrm{CAG}$ & MAR & MSV & LES & CER & GOR \\
\hline ORB & $* * * *$ & & & & & & & & & \\
\hline TAR & 0.010 & $* * * *$ & & & & & & & & \\
\hline ORI & 0.049 & 0.063 & $* * * *$ & & & & & & & \\
\hline SAN & 0.079 & 0.090 & 0.013 & $* * * *$ & & & & & & \\
\hline CAG & 0.118 & 0.130 & 0.033 & 0.015 & $* * * *$ & & & & & \\
\hline MAR & 0.083 & 0.094 & 0.019 & 0.016 & 0.018 & $* * * *$ & & & & \\
\hline MSV & 0.068 & 0.080 & 0.014 & 0.025 & 0.036 & 0.019 & $* * * *$ & & & \\
\hline LES & 0.087 & 0.095 & 0.020 & 0.032 & 0.046 & 0.027 & 0.013 & $* * * *$ & & \\
\hline CER & 0.108 & 0.124 & 0.044 & 0.041 & 0.046 & 0.031 & 0.025 & 0.037 & $* * * *$ & \\
\hline GOR & 0.096 & 0.109 & 0.032 & 0.034 & 0.040 & 0.025 & 0.015 & 0.023 & 0.003 & $* * * *$ \\
\hline
\end{tabular}

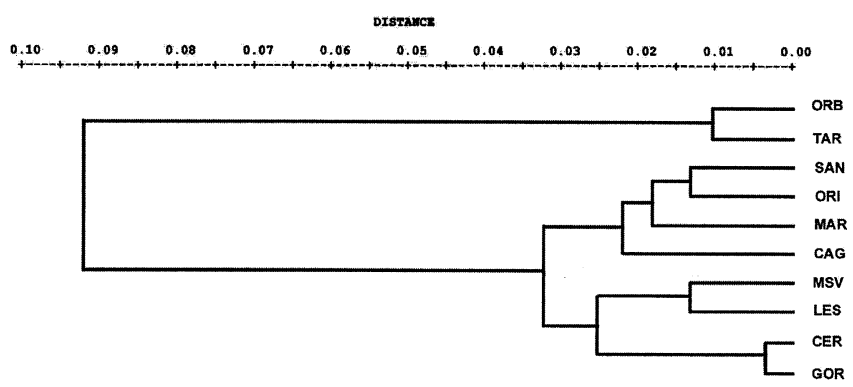

Fig. 2. UPGMA dendrogram based on Nei's (1978) genetic distances. Population abbreviations are as in Fig. 1.

studies carried out by Maltagliati (1999) on 11 Mediterranean samples. Only three samples are in common between the two studies but the overall patterns concur in showing a northern-central Tyrrhenian most differentiated cluster, a southern Tyrrhenian and an Adriatic one. Our data add further information, indicating that the populations from southern Sardinia (ORI, SAN, CAG) belong to the southern Tyrrhenian cluster, identifying the boundary between northern and southern Tyrrhenian groups at about $41^{\circ} \mathrm{N}$. The levels of genetic differentiation among the studied groups of populations are slightly higher than those previously reported in the literature for this species (Maltagliati, 1998, 1999), probably because of the different set of loci studied. The levels of gene flow estimated from our data indicate that this evolutionary force acts very weakly on killifish populations, $N m=0.46$, a value well below $N m=1$. Under this limit, the stochastic effect of genetic drift is stronger than the homogenising force of gene flow. The genetic subdivision of $A$. fasciatus is not surprising, its biological features accounting for a limited vagility (demersal eggs and lack of planktonic larval stages), coupled with the fragmentation typical of brackish water habitats. The current genetic population structure of this species seems, therefore, due either to occasional gene flow, maintaining the isolation by distance (Maltagliati, 1999) and to a number of evolutionary forces concurring in moulding the gene pool of the species, either of stochastic (genetic drift) or deterministic (selection) nature. Indeed, the genetic relationships within each population group do not reveal any geographic arrangement, except for the Adriatic cluster (see Fig. 2).

As to genetic variability, the observed values are higher than those reported in the literature. The observed heterozygosities range between 0.045 and 0.147 , while previous electrophoretic studies evidenced lower values (0.013-0.062; Maltagliati, 1999). This divergence could be due to the mentioned differences in the studied set of loci, and mostly to the different electrophoretic techniques used: starch gel electrophoresis generally has a higher resolution power than agarose electrophoresis, allowing to gather a greater bulk of data and being considered " $\ldots$ the system of choice for most population studies" (Hoelzel, 1998). For example, two loci found to be monomorphic by Maltagliati (IDH-2, MDH-1) 
are polymorphic in our samples, with less common alleles at high frequencies. The main objective of this work was the comparison of population genetic variability with the kind of environmental disturbance, either natural or human-induced. The basic idea was that natural stress should selectively promote genetic variability as a powerful resource to respond efficaciously to environmental challenge. This is in agreement with the Red Queen hypothesis, stating that genetic uniformity is dangerous to animal populations (Van Valen, 1973), which use genetic variability as a base to reply with adaptation to environmental changes. On the contrary, human-induced disturbance occurs very rapidly, causing a loss of genetic variability through the genetic erosion process. According to this view, killifish populations from brackish naturally stressed environments should be characterised by higher levels of genetic variability than those from habitats with anthropogenic disturbance. To test this hypothesis, pairs of samples were taken from nearby habitats characterised by natural stress vs. human impacted ones, as reported in Table 3 The genetic variability values, in particular heterozygosity, range widely, being very different in geographically and genetically very close populations. The population pair ORB-TAR from the Tyrrhenian Sea represents the most striking example, showing $H_{\mathrm{o}}$ values that are about twofold in Tarquinia sample (0.147 vs. 0.079), a highly significant difference $(P<0.001$, significant even after Bonferroni correction). The sample from Tarquinia comes from a small saltern where environmental physical-chemical parameters undergo dramatic seasonal and daily changes due to the strong evaporation of the laminar water system. Studies on the structure of the macrozoobenthic community confirm a main ecological role for such environmental challenges, discarding relevant impacts of anthropogenic pollutants (Nascetti et al., 1998). On the contrary, Orbetello lagoon is a large brackish basin suffering from increasing pollution from urban and aquaculture waters (Lenzi, 1992), that caused severe anoxic crises in 1992 and 1993 entailing high fish mortality through most of the lagoon (Lardicci et al., 1997, 2001). This strong demographic reduction in the size of the local population could be responsible for the remarkable deficit of heterozygotes observed at PGM-1 locus and the marked loss of genetic variability observed in killifish from Orbetello lagoon. The application of the Wilcoxon sign-rank test to our data does not provide evidence of recent bottlenecks in this population, as was recently shown by Maltagliati (2002). This discrepancy could be due to the already mentioned differences in the set of studied loci or in the sampling scheme. Nevertheless, both data sets witness at least a strong reduction in Orbetello killifish density. This probably caused the fragmentation of the population in many small sub-demes, with a random local loss of alleles and/or genotypes, resulting in a slight difference of sub-demes allele frequencies. The observed heterozygote deficiency could therefore be due either to a stochastic loss of genotypes or the sampling of the studied specimens from different sub-demes (the sampling has been actually carried out in many areas of the lagoon).

A concordant trend (although not statistically significant) is observed when comparing the southern Sardinian populations CAG vs. the small lagoon of SAN, showing a mean $H_{\mathrm{o}}$ of 0.096 in the human disturbed sample from CAG, while showing a value of 0.130 in SAN. Santa Gilla lagoon (CAG) suffers from urban and industrial discharge, requiring a restoration programme, which is now in progress (Degetto et al., 1997). On the contrary, the small lagoon of Sant'Antioco (SAN) is a habitat with environmental features very close to those of the nearby marine environment and does not suffer from any kind of anthropogenic impact (our observation). Within the Adriatic cluster of samples, we have observed a general low variability, particularly evident in the northernmost samples, GOR and CER. The Adriatic Sea represents an overall disturbed habitat, with the northern part strongly affected by pollution, causing persistent hypoxic conditions with a strong loss of local fauna (Benovic et al., 2000; Nemanic et al., 2002). Also, the paleogeographic history of the Adriatic Sea has probably played an important role in moulding the genetic structure of current killifish Adriatic populations. In particular, the lowering of the sea level during the Pleistocenic glaciations has triggered recent colonisation of the northern Adriatic sea waters and coastal lagoons from southern refugia for many marine and brackish species. Therefore, the relevance of biogeographic historical factors in determining the low genetic variability of Adriatic killifish could not be overlooked, as evidenced for many brackish species (Cognetti and Maltagliati, 2000).

In conclusion, the reported data are in agreement with the hypothesis, already advanced in our preliminary data (Scialanca et al., 2000), that a link exists between the levels of genetic variability of local populations and the kind of environmental disturbance they undergo, as already demonstrated for many fish species (Smith et al., 1991; Nielsen et al., 1997; Lemaire et al., 2000). The evidenced trend suggests that human impacted habitats host genetically impoverished populations and outlines the monitoring of genetic variability levels as a sensitive tool to detect environmental disturbance at early stages. This idea needs to be supported by further evidence from future research aimed at providing a stronger support to the proposed hypothesis by carrying out the collection of genetic and environmental data simultaneously and in a standardised and planned way.

\section{Acknowledgements}

This study was fully supported by the Italian Ministero dell'Università e Ricerca Scientifica e Tecnologia (MURST) within a national research project on biodiversity in brackish waters (1997 and 1999). We are indebted to Dr. P. Arduino for reviewing the manuscript text and to Dr. D. Canestrelli for his help with statistical analyses on bottleneck test.

We thank the three referees who revised the manuscript for their useful observations. 


\section{References}

Archie, J.W., 1985. Statistical analysis of heterozygosity data: independent sample comparisons. Evolution 39, 623-637.

Ayala, F., Powel, J.R., Tracey, M.L., Mourao, C.A., Perez-Salas, S., 1972. Enzyme variability in Drosophila Willistoni group. IV. Genetic variation in natural populations of Drosophila Willistoni. Genetics 70, 113-139.

Barton, N.H., Turelli, M., 1990. Evolutionary quantitative genetics: how little do we know? Ann. Rev. Genet. 23, 337-370.

Benovic, A., Lucic, D., Onofri, V., 2000. Does change in an Adriatic Hydromedusan fauna indicate an early phase of marine ecosystem destruction? Mar. Ecol. 21, 221-231.

Brewer, G.J., Sing, C.F., 1970. An Introduction to Isozyme Techniques. Academic Press, New York.

Cognetti, G., 1994. Colonization of brackish waters. Mar. Poll. Bull. 28, 583-586.

Cognetti, G., 1999. Conservation strategies in the Mediterranean. Aquatic Conserv. Mar. Freshw. Ecosyst. 9, 509-515.

Cognetti, G., Maltagliati, F., 2000. Biodiversity and adaptive mechanisms in brackish water fauna. Mar. Poll. Bull. 40, 7-14.

Crow, J.F., 1957. Genetics of insect resistance to chemicals. Ann. Rev. Entomol. 2, 227-246.

Crow, J.F., Aoki, K., 1984. Group selections for a polygenic behavioural trait: estimating the degree of a population subdivision. Proc. Nat. Acad. Sci. USA 81, 6073-6077.

Degetto, S., Schintu, M., Contu, A., Sbrignadello, G., 1997. Santa Gilla lagoon (Italy): a mercury sediment pollution case study. Contamination assessment and restoration of the site. Sci. Tot. Env. 204, 49-56.

Diehl, W.J., Gaffney, P.M., Koehn, R.K., 1986. Physiological and genetic aspects of growth in the mussel Mytilus edulis. I. Oxygen consumption, growth and weight loss. Physiol. Zool. 59, 201-211.

Dufresne, F., Bourget, E., Bernatchez, L., 2002. Differential patterns of spatial divergence in microsatellite and allozyme alleles: further evidence for locus-specific selection in the acorn barnacle, Semibalanus balanoides? Mol. Ecol. 11, 113-123.

Harris, H., Hopkinson, D.A., 1976. Handbook of Enzymes Electrophoresis in Human Genetics. North Holland Publishing Co., New York.

Hartl, D.L., Dykhuize, D.E., Dean, A.M., 1985. Limits of adaptation: the evolution of selective neutrality. Genetics 111, 655-674.

Heuts, M.J., 1948. Adaptive properties of carriers of certain gene arrangements in Drosophila pseudoobscura. Heredity 2, 63-75.

Hoelzel, A.R., 1998. Molecular Genetic Analysis of Populations. Oxford University Press, Oxford.

Hoffmann, A.A., Parsons, P.A., 1991. Evolutionary Genetics and Environmental Stress. Oxford University Press, Oxford.

Kimura, M., Crow, J.F., 1964. The number of alleles that can be maintained in a finite population. Genetics 49, 725-738.

Lardicci, C., Como, S., Castelli, A., 1997. Analysis of macrozoobenthic community structure after severe dystrophic crises in a Mediterranean coastal lagoon. Mar. Pollut. Bull. 34, 536-547.

Lardicci, C., Como, S., Corti, S., Rossi, F., 2001. Recovery of the macrozoobenthic community after severe dystrophic crisis in a Mediterranean coastal lagoon (Orbetello, Italy). Mar. Pollut. Bull. 42, 202-214.

Lemaire, C., Allegrucci, G., Naciri, M., Bahri-Sfar, L., Kara, H., Bonhomme, F., 2000. Do discrepancies between microsatellite and allozyme variation reveal differential selection between sea and lagoon in the sea bass (Dicentrarchus labrax)? Mol. Ecol. 9, 457-467.

Lenzi, M., 1992. Experiences for the management of Orbetello Lagoon: eutrophication and fishing. Sci. Tot. Env. (Suppl.), 1189-1198.

Levine, R.P., 1952. Adaptive responses of some third chromosome types of Drosophila pseudoobscura. Evolution 6, 216-233.

Luikart, G., Sherwin, W.B., Steele, B.M., Allendorf, F.W., 1998. Usefulness of molecular markers for detecting population bottlenecks via monitoring genetic change. Mol. Ecol. 7, 963-974.
Maltagliati, F., 1998. A preliminary investigation of allozyme genetic variation and population geographic structure in the killifish Aphanius fasciatus Nardo (Cyprinodontidae) from Italian brackish-water habitats. J. Fish Biol. 52, 1130-1140.

Maltagliati, F., 1999. Genetic divergence in natural populations of the Mediterranean brackish-water killifish Aphanius fasciatus. Mar. Ecol. Prog. Ser. 179, 155-162.

Maltagliati, F., 2002. Genetic monitoring of brackish-water populations: the Mediterranean toothcarp Aphanius fasciatus (Cyprinodontidae) as a model. Mar. Ecol. Prog. Ser. 235, 257-262.

Nascetti, G., Scardi, M., Fresi, E., Cimmaruta, R., Bondanelli, P., Gatti, S., Blasi, S., Serrano, S., Meschini, L., Lanera, P., Plastina, N., Valiante, M., Vinci, D., 1998. Caratterizzazione ecologica delle saline di Tarquinia al fine di un loro recupero e per lo sviluppo dell' acquacoltura. Biol. Mar. Medit. 5, 1365-1374.

Neel, H., 1973. Private variants and the frequency of mutation among South American Indians. Proc. Nat. Acad. Sci. USA 70, 3311-3315.

Nei, M., 1978. Estimation of average heterozygosity and genetic distance from a small number of individuals. Genetics 89, 583-590.

Nemanic, T.M., Leskovsek, H., Horvat, M., Vriser, B., Bolje, A., 2002. Organotin compounds in the marine environment of the Bay of Piran, northern Adriatic Sea. J. Environ. Monit. 4, 426-430.

Nevo, E., 2001. Evolution of genome-phenome diversity under environmental stress. PNAS 98, 6233-6240.

Nevo, E., Ben-Shlomo, R., Lavie, B., 1984. Mercury selection of allozymes in marine organisms: prediction and verification in nature. PNAS 81 , $1258-1259$.

Nielsen, E.E., Hansen, M.M., Loeschcke, V., 1997. Analysis of microsatellite DNA from old scale samples of Atlantic Salmon Salmo salar: a comparison of genetic composition over 60 years. Mol. Ecol. 6, 487-492.

Pasteur, N., Pasteur, G., Bonhomme, F., Catalan, J., Britton-Davidian, J., 1987. Manuel de génétique par électrophorèse des protéines. Collection technique et documentation. Lavoisier, Paris.

Piry, S.G., Luikart, G., Cornuet, J.M., 1999. BOTTLENECK: a computer program for detecting recent reductions in the effective population size using allele frequency data. J. Hered. 90, 502-503.

Poulik, M.D., 1957. Starch gel electrophoresis in a discontinuous system of buffers. Nature 180, 1477.

Richardson, B.J., Baverstock, P.R., Adams, M., 1986. Allozyme Electrophoresis. A Handbook for Animal Systematics and Population Studies. Academic Press, San Diego, CA, USA.

Scialanca, F., Ungaro, A., Cimmaruta, R., Nascetti, G., 2000. Struttura genetica di popolazioni di Aphanius fasciatus: relazioni con lo stress ambientale. Atti del X Congresso Nazionale della Società Italiana di Ecologia, Pisa, 52.

Selander, R.K., Hunt, W.G., Yang, S.Y., 1979. Protein polymorphism and genetic heterozygosity in two European subspecies of the house mouse. Evolution 23, 370-390.

Selander, R.K., Smith, M.H., Yang, S.Y., Johnson, W.E., Gentry, J.B., 1971. Biochemical polymorphism and systematics in the genus Peromyscus. Variation in the old field mouse (Peromyscus polionotus). Univ. Tex. Publ. (Stud. Genet. 6) 103, 49-69.

Shaklee, J.B., Allendorf, F.W., Morizot, D.C., Whitt, G.S., 1990. Gene nomenclature for protein-coding loci in fish. Trans. Amer. Fish. Soc. 119, $2-15$.

Shaw, C.R., Prasad, R., 1970. Starch gel electrophoresis of enzymes: a compilation of recipes. Biochem. Genet. 4, 297-320.

Smith, P.J., Francis, R.I.C.C., Mc Veagh, M., 1991. Loss of genetic diversity due to fishing pressure. Fish. Res. 10, 309-316.

Sneath, P.H.A., Sokal, R.R., 1973. Numerical Taxonomy. W.H. Freeman \& Co, San Francisco, CA, USA.

Soltis, D.E., Haufler, C.H., Darrow, D.C., Gastony, G.J., 1983. Starch gel electrophoresis of ferns: a compilation of grinding buffers, gel and electrode buffers, and staining schedules. Amer. Fern. J. 73, 9-27. 
Swofford, D.L., Selander, R.B., 1989. Biosys-1: a Computer programme for the analysis of allelic variation in genetics and biochemical systematics. Release 1.7. Dept. of Genetics and Development. University of Illinois, Urbana-Champaign, IL.

Tortonese, E., 1986. Cyprinodontidae. In: Whitehead, P.J.P., Bauchot, M.L., Hureau, J.C., Nielsen, J., Tortonese, E. (Eds.), Fishes of the Northeastern Atlantic and Mediterranean, vol. 2. Unesco, Bungay, pp. 623-626.
Van Valen, L., 1973. A new evolutionary law. Evol. Theory 1, 1-30.

Watt, W.B., 1985. Bioenergetics and evolutionary genetics: opportunities for a new synthesis. Am. Nat. 125, 118-143.

Wright, S., 1943. Isolation by distance. Genetics $28,114-138$.

Wright, S., 1951. The genetical structure of populations. Ann. Eugen. (London) 15, 323-345. 